\title{
OLVASS FELESLEGESET!
}

\section{- SiK ENDRE ÁLlANDÓ ROVATA -}

Amióta a szakmában vagyok, harcolok a túlzásba vitt specializáció, a semmiről való mindentudás irányába mutató szakszerűség eluralkodása ellen. Természetesen a kudarc elkerülhetetlen, de kedvenc fegyverem ennek ellenére hasznossá válhat mások kezében is. Arról van szó, hogy világéletemben vigyáztam arra, hogy ha nyaralni mentem vagy feleslegesnek tűnő konferencián üldögéltem, akkor olyan tanulmányokat olvassak, amelyeknek semmi köze nem volt ahhoz, amivel akkor éppen foglalkoztam. Gondosan mindig valamilyen feleslegeset olvastam. Ezek között sok volt olyan, amibe beleszerettem, s félretettem, hogy valaha talán valakinek a kezébe adhatom, hogy foglalkozzon vele behatóbban, mert a mű valamilyen szempontból zseniális.

Az alábbi ismertetés/elemzés egy olyan kutatási irányzatba illeszkedik, amelyik alig létezik Magyarországon: jobb híján nevezzük válságszociológiának. A válsággal foglalkozó szociológusokat az foglalkoztatja, hogy hogyan reagál a társadalom (vagy annak egy kisebb csoportja) egy válságra, egy katasztrófára, egy csapásra. ${ }^{1} \mathrm{~A}$ Debreceni Egyetem kiváló doktorandusza egy olyan művet elemez ${ }^{2}$, amely egy katasztrófa ${ }^{3}$ „készen kapott adatainak”4 elemzésén keresztül vizsgálja az emberi társadalom müködését.

${ }^{1}$ A válság szociológiai vonatkozásairól lásd még Sik Endre (1995) Itt van a válság, itt van újra, s mély, mint mindig énnekem... In: Mozgó Világ, 4.: 49-57. http://www.academia.edu/36160156/Itt_a_ v\%C3\%A1ls\%C3\%A1g_itt_van_\%C3\%BAjra_s_m\%C3\%A9ly_mint_mindig_\%C3\%A9nnekem.

${ }^{2}$ Bruno S. Frey - David A. Savage - Benno Torgler (2011): Who perished on the Titanic? The importance of social norms. In: Rationality and Society, 23(1): 35-49. DOI: 10.1177/1043463110396059

${ }^{3}$ A szerzőhármas egy másik - az itt elemzettel nagyban átfedő tartalmú - művében (Bruno S. Frey David A. Savage - Benno Torgler: Behavior under Extreme Conditions: The Titanic Disaster. In: Journal of Economic Perspectives, 25 (1): 209-222. https://www.aeaweb.org/articles?id=10.1257/jep.25.1.209) a katasztrófa időtartamának hatását is vizsgálta oly módon, hogy a Titanic katasztrófáját a Lusitána gyorsabb (torpedó általi) elsüllyedésével veti egybe. Azt találták, hogy a gyorsabb süllyedés, vagyis a nagyobb katasztrófa túlélésére a fiatalabbak, az erősebbek esélye nagyobb, ilyenkor a magasabb osztályhelyzet, illetve a társadalmi normák kevésbé érvényesülnek.

${ }^{4}$ A módszerről lásd A diszkrimináció mérése készen kapott kísérletek (KKK) segítségével (2012) (Horzsa Gergellyel) In: Sik Endre - Simonovits Bori (szerk.): A diszkrimináció mérése. TáTK, Budapest: 186- 201. http://issuu.com/tarki_research/docs/diszkriminacio_merese_sik_simonovits/1 


\title{
Ki veszett oda a Titanic katasztrófájában?, avagy a társadalmi norma fontossága ${ }^{1}$
}

\author{
BALUJA PETRA ${ }^{2}$
}

A válságszociológia alapkérdése, hogy vajon mely egyéni és társadalmi faktorok kombinációja határozza meg a túlélést egy élet-halál helyzetben? Ilyen élet-halál helyzetre alkalmas példa a Titanic katasztrófája.

A Titanic 1914. április 14-én ütközött neki egy jéghegynek, majd 2 óra és 40 perc leforgása alatt elmerült az Atlanti-óceán habjaiban, okozva ezzel 1517 ember, azaz utasai közel 2/3-ának (teljes létszámuk, legénységgel együtt: 2223 fő volt) halálát. Ez volt a boldog békeidők történelmében a leghíresebbé vált tengeri katasztrófa. Annál is inkább, mert korában élen járó technikai felszereltsége, tapasztalt legénysége miatt általánosan elterjedt volt a gondolat, miszerint a Titanic „elsüllyeszthetetlen”. Napjainkban is valóságos mítosz lengi körül a katasztrófát. ${ }^{3}$

A vizsgált kutatásban azt az öt tényező szerepét elemzik, amelyekről feltételezték, hogy legerősebben hatottak a túlélés valószínűségére. Elsőként említik a fedélzeten utazók három egyéni jellemzőjét, ezek: a fizikai erőnlét, a birtokolt anyagi javak, a nemzetiség. Ezek mellett két társadalmi tényezőt határoztak meg: az egyén egyedül vagy csoportosan utazott, illetve társadalmi normákat. A kutatók hipotézisei a következők voltak:

1. A nagyobb fizikai erőnléttel, illetve anyagi erőforrásokkal rendelkező (kabinosztályok szintjei) és a brit nemzetiségü utasok túlélésének valószínűsége nagyobb, mint a gyengébb, szegényebb és nem brit nemzetiségű útitársaiknak.

${ }^{1}$ Bruno S. Frey - David A. Savage - Benno Torgler (2011): Who perished on the Titanic? The importance of social norms. In: Rationality and Society, 23(1): 35-49.

${ }^{2}$ Debreceni Egyetem, Humán Tudományok Doktori Iskola Szociológia és társadalompolitika doktori program, doktorandusz.

${ }^{3}$ A legismertebb Titanic-kutató Tim Maltin, a 2010-es években végzett kutatásai során megállapította, hogy a katasztrófát szerencsétlen véletlenek összefüggő sorozata okozta: az 1912-es évben nagyobb jégzajlás volt jellemző az Atlanti-óceánon, a hajó készítéséhez nem megfelelő minőségű vascsavarokat használtak fel, melyek rideg és merev anyagukból adódóan, terhelésre könnyen törékennyé váltak, továbbá a hajó 5 rekesz sérülése esetén maradt volna fent a vízen, ehelyett 6 rekesz sérült meg, és kevesebb mentőcsónakot építettek bele, mint az szükségeltetett volna (Bencze Áron (2012): Száz éve süllyedt el a Titanic - kiderült, mi okozta a katasztrófát. http://www.csaladhalo.hu/cikk/szinek/szaz-eve-sullyedt-el-titanic-kiderult-mi-okozta-katasztrofat (Utolsó letöltés: 2016.05.30.) 


\section{OLVASS FELESLEGESET!}

2. Azok az egyének, akik barátaikkal, rokonaikkal utaztak, nagyobb eséllyel élték túl a katasztrófát, mivel több emberi támogatásra számíthattak az élet-halál helyzetben. Katasztrófa esetében is érvényesül az az alapvető emberi norma, miszerint a „nőket és gyermekeket elsőként” kell megmenteni.

\section{Az adatok}

A Titanic katasztrófája interpretálható egy „majdnem természetes kísérlet”-ként. Azért bizonyulhat az eset „majdnem természetes” kísérletnek, mert minden fedélzeten utazó sokkos állapotba került a katasztrófa során, így képtelenek voltak meghatározni, hogy vajon bármelyik döntésükkel tényleg a túlélésüket segítik-e elő. Ez a tényező a kísérlet jellegéhez a kutatók egyik hipotézisével kapcsolható: a süllyedést megelőzően követett vagy követendő társadalmi normák érvényesek maradtak, vagy a körülmények extremitásából következő pszichés állapotváltozás felülírta-e azokat? A kutatásban szereplő adatbázis közel 100 éves feljegyzések alapján készült el, amely mivel nem volt túl részletes, a kutatók hozzákapcsolták a Titanic Enciklopédiájából és más kutatásból származó empirikus adatokat.

Az elemzés kiindulópontja az a táblázat, amelyben az utasok adatainak, az elemzés számára hasznos megoszlásai láthatók. Eszerint a fedélzeten levő utasok 32\%-a élte túl a katasztrófát, $68 \%$-uk veszett oda. A nők aránya az utasok között $22 \%$ volt, a 16 és 50 évesek közötti felnőtt korosztály arányát 89\%-ra becsülték a rendelkezésre álló források alapján. Az utasok 15-15\%-a az első és a második osztályon és a többség (32\%) a harmadosztályon utazott. ${ }^{4} \mathrm{Az}$ emberek 38\%-a társaságban, tehát családdal vagy barátokkal, 22\%-uk egyedül utazott. Az utasok társadalmi csoportokba sorolását a túlélők elbeszélései, jegyük azonosítója, és kabinjaik elhelyezkedése alapján végezték el. Az utasok között 43 alkalmazott volt. Az utasok több mint fele brit származású volt, ezenkívül viszonylag többen voltak az amerikaiak (19\%), írek és svédek (5-5\%).

\section{A túlélést meghatározó tényezők}

Az elemzés első lépésében a kutatók az egyének túlélésében lényegesnek becsült faktorok (fizikai erőnlét, „osztályhelyzet”, nemzetiség, csoporthatás) és a túlélési esély korrelációját vizsgálják.

A férfiak jobb erőnlétéből következő nagyobb túlélési esély hipotézise megdőlt: a férfiak túlélési esélye 50\%-kal alacsonyabb az átlagosnál, s az 55 év feletti férfiak túlélési esélye alacsonyabb fiatalabb társaikénál.

${ }^{4}$ A többiek a hajó legénysége, személyzete voltak, akik a fedélzeten, a hajtóműveket irányító szobában, illetve az utasokat kiszolgáló egységekben foglaltak helyet. 


\section{OLVASS FELESLEGESET!}

A hajó süllyedésekor a legkedvezőbb helyzetben a fedélzeten lakó első osztályon utazó utasok voltak, ugyanis ők jutottak leghamarabb pontos információkhoz a személyzettől és ők tudtak a mentőcsónakok pontos helyéről, s jó anyagi helyzetükből adódóan ilyen esetben is a méltányos bánásmódot várták el a mentés során. A másod- és harmadosztályról sokkal nehezebben, vagy egyáltalán nem szereztek tudomást a fent zajló eseményekről. A vizsgálat kimutatta, hogy legelőnyösebb helyzetben a magas anyagi javakkal rendelkező nők és gyerekeik voltak a katasztrófa éjszakáján.

Mivel a hajó Nagy-Britanniában épült és brit legénység vezette, a szerzők hipotézise szerint a brit származású utasoknak nagyobb kellett, hogy legyen az esélye a túlélésre. Azonban a számítások szerint a brit utasoknak 11\%-kal volt kevesebb esélyük az életben maradásra, mint a többi nemzetiségnek. Ennek oka az volt, hogy például az amerikaiak nagyobb valószínűséggel segítették egymás túlélését.

Összességében tehát a legnagyobb túlélési esélyeik a nőknek és a gyerekeiknek voltak. Azok az utasok is előnyre tehettek szert, akik gyerekekkel utaztak, mintegy 37\%-kal nagyobb esélyük volt a túlélésre. A társas támogatás tényezője felbukkan, de egyértelmúen nem támasztható alá a rendelkezésre álló források alapján.

Amikor a szerzők a kutatás során felállított hipotézisek mögötti ok-okozati összefüggéseket vizsgálták, az előzőekben ismertetett eredményeken túl azt találták, hogy:

A nőknek és a személyzetnek (ők csak az első osztályon dolgoztak) volt a legnagyobb esélye arra, hogy túléljék a katasztrófát.

A becslések megengedik, hogy elvessék a társadalmi normákhoz kapcsolódó hipotézist. Ugyanis ezen normák jelentősége elenyészik az extrém kényszerítő feltételek mellett. Az eredmények azt jelzik, hogy valóban a nőknek és gyermekeknek volt magasabb esélyük a túlélésre. Összhangban a regressziós eredményekkel (gyerekek: $15 \%$ és utasok gyerekkel: 17\%), a gyerekek és az utasok gyerekkel 13\% és 17\%-kal nagyobb esélyük volt a felnőtt utasokhoz viszonyítva. Ez az eredmény megegyezik azzal a feltételezéssel, hogy a „nőket és gyermekeket elsőként” elv valóban a legfontosabb követendő norma volt a Titanic süllyedésekor.

\section{Összefoglalóan}

A Titanic katasztrófájának empirikus vizsgálata fontos példa arra, milyen tanulságos lehet a katasztrófahelyzetek valós adatai alapján vizsgálni a társadalmat. Meglátásom szerint, míg a világhírhedtté vált katasztrófa okainak széles skáláját tárták már fel a kutatók (mint az indulás körülményei, a hajó elkészítésének hibái, a süllyedés szerencsétlen és komplex módon összefüggő körülményei), addig a hajón utazó emberi felelősséggel és emberek közötti viszonyokkal alig foglalkoztak a társadalom- 


\section{OLVASS FELESLEGESET!}

tudósok. Az 1997-ben elkészült, több Oscar-díjat elnyert film egyik jelenete utal arra, hogy a hajón utazó elitnek milyen nagy szerepe lehetett a katasztrófa kialakulásában: a hajóval minden tekintetben a legnagyobbak és a legelsők szerettek volna lenni, így a tervezettnél korábbi időpontban akartak az Amerikai Egyesült Államokba megérkezni, ezért a hajó más irányt vett ennek érdekében.

A Titanic modernsége és fenségessége mellett, kicsiben modellezte a „boldog békeidők" társadalmi osztályok szerinti tagoltságát (külön utaztak az osztályok, a harmadosztályon haltak meg legtöbben, konzerválva azt a nézetet, mely szerint a társadalomnak kevésbé értékes tagjai ezek az emberek), a társadalmi mobilitás teljes kizárásával. 